\title{
Metastatic Melanoma of the Parotid Glands Bilaterally
}

\author{
BP Cengız 1 , M Acar², C Aksay², YK Cantürk
}

\begin{abstract}
Melanoma is the most serious form of skin cancers and life-time risk of melanoma is increasing rapidly both in men and women. Melanoma in the parotid gland is seen rarely and it is more likely to be metastatic disease. We present here a rare case of metastatic malignant melanoma from the forehead skin to the parotid glands bilaterally.
\end{abstract}

Keywords: Bilateral, melanoma, metastasis, parotid

\section{Melanoma metastático de las glándulas parótidas bilateralmente}

\author{
BP Cengız'1 , M Acar², C Aksay², YK Cantürk ${ }^{3}$
}

\begin{abstract}
RESUMEN
El melanoma es la forma más grave de los cánceres de piel y tiempo de vida riesgo de melanoma está aumentando rápidamente tanto en los hombres y mujeres. Melanoma en la glándula parótida se considera raramente y es más probable que la enfermedad metastásica. Aqui os presentamos una caja rara de melanoma maligno metastásico de la piel frente a las glándulas parótidas bilateralmente.
\end{abstract}

Palabras clave: Bilateral, melanoma, metástasis parotídea

West Indian Med J 2016; 65 (2): 401

\section{INTRODUCTION}

Melanoma is a neoplasm of melanocytes or of the cells that develop from melanocytes. Melanoma is an important healthcare issue because the incidence of melanoma has increased dramatically over the last four decades (1). Melanomas are localized in order of frequency: head and neck region, lower extremities, trunk, upper extremities or mucous membranes. Nearly one-fifth of the melanomas are detected in the head and neck region. These tumours are rarely presented in the parotid gland. If melanoma is diagnosed in the parotid gland, it is usually assumed to be of metastatic origin $(2,3)$.

We present here a rare case of metastatic melanoma that presented in the parotid glands bilaterally from a primary on the forehead.

\section{CASE REPORT}

A 78-year old male presented with bilateral masses in both

From: ${ }^{1}$ Department of Pathology, ${ }^{2}$ Department of Otorhinolaryngology and ${ }^{3}$ Department of Nuclear Medicine, Yunus Emre State Hospital, Eskişehir, Turkey.

Correspondence: Dr BP Cengiz, Department of Pathology, Yunus Emre State Hospital, Eskişehir 26020, Turkey. E-mail: betip76@ yahoo.com parotid glands region which were rapidly increasing in size for over one month. Physical examination revealed two masses with $1 \times 0.9 \mathrm{~cm}$ and $0.5 \times 0.5 \mathrm{~cm}$ in diameters, respectively in the right and left parotid region. The masses were nontender and nonfixed to skin and underlying structures. Ultrasonography of the parotid glands bilaterally revealed multiple lymph nodes with a maximum of $1.2 \mathrm{~cm}$ in diameter in the right and left parotid gland. Pathological fludeoxyglucose (FDG) uptake was detected within the left and right parotid gland with positron emission tomography computed tomography (PET CT) imaging (Fig. 1). Fine-needle aspiration biopsy of both parotid glands were performed.

Fine-needle aspiration cytology from these masses yielded low cellular smears with presence of few dispersed cells round to polygonal. Considering the site and morphology, a diagnosis of myoepithelioma was considered and an urgent excision was advised. Right partial neck dissection with total right parotidectomy was performed for primary parotid gland tumour. The surgical material was sent for histopathological examination. Under microscopical examination, the peri- and intra-parotid lymph nodes were seen and the adjacent parotid tissue was infiltrated by malignant tumour. Malignant tumoural lesion consisted of epitheloid neoplastic cells with foamy cytoplasm, marked cytologic atypia, nuclear grooves, 


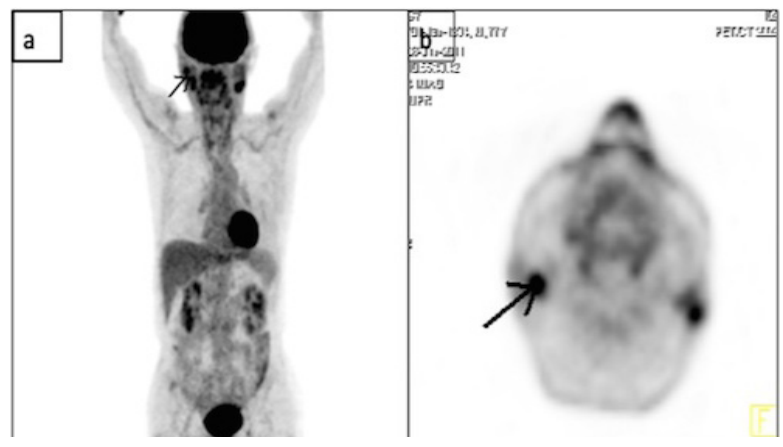

Fig. 1: Pathological fludeoxyglucose uptake was detected within the left and right parotid gland (PET-CT image, axial (a) and coronal (b) sections).

large eosinophilic nucleoli and abundant atypical mitotic figures. Mitotic figures were counted as $12-15$ in the 10 high power fields (Fig. 2). Also, tumour necrosis was observed in the focal area. In light of these findings, melanoma and myoepithelial carcinoma were considered in the differential diagnosis.

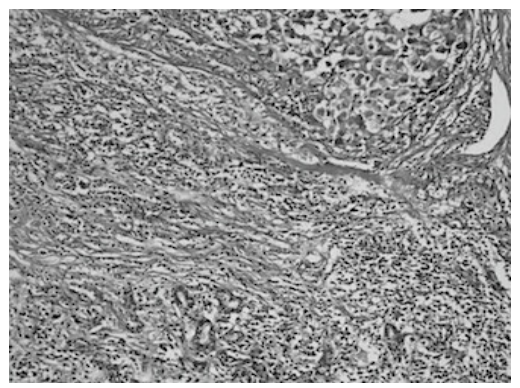

Fig. 2: Nests of tumour cells infiltrate into the adjacent parotid gland parenchyma. There is mitotic activity and nuclear polymorphism (haematoxylin/eosin $\times 200$ ).

Immunohistochemically, neoplastic cells showed strong nuclear and cytoplasmic reactivity for S-100 protein and vimentin and mainly for MART-1. However, HBM45 was stained positive focally. The patient had a history of melanoma which was located in the forehead and was excised six months previously. Thus, diagnosis of metastatic melanoma to the bilateral parotid glands from a forehead skin primary was confirmed.

Afterward, the patient underwent left partial neck dissection with total left parotidectomy and metastatic lymph nodes were detected. Additionally, intraglandular lymph nodes were involved by metastatic melanoma. The patient received chemoradiotherapy in the oncology department. After seven months, PET-CT revealed no evidence of tumour (Fig. 3).

\section{DISCUSSION}

Metastatic tumours comprise about $5 \%$ of all malignant tumours for salivary glands. The large majority of metastases are located in the parotid gland. The most common primary tumours of the salivary glands are squamous cell carcinomas and melanomas (2). The parotid lymph nodes drain a large area of the head and neck region, including the forehead, an-

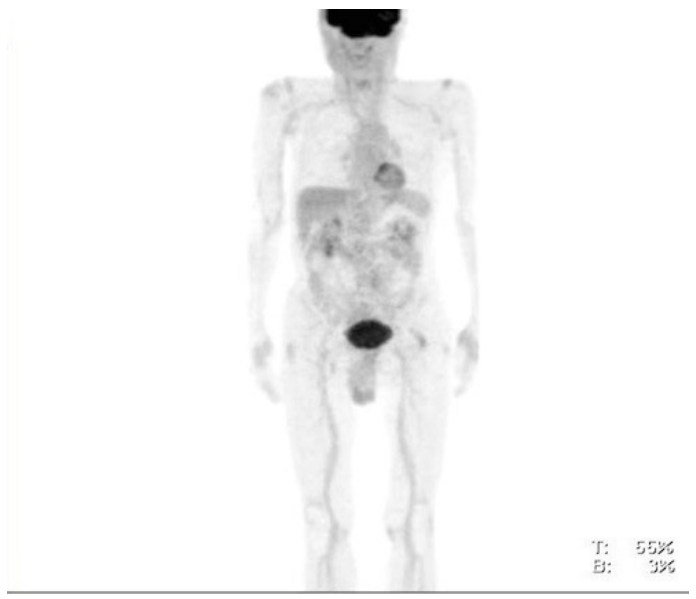

Fig. 3: Pathological fludeoxyglucose (FDG) uptake was not detected elsewhere within body positron emission tomography- computed tomography (PET-CT) image, coronal section).

terior, frontal and temporal region, eyelids and conjunctiva, lacrimal gland, anterior ear, external auditory meatus, eustachian tube, cranial vault and posterior neck regions (4). Direct invasion of melanoma from adjacent soft-tissue or skin is also a possible mechanism for parotid gland involvement (5). Yarington (6) reported a series of 250 parotidectomy cases in which $25 \%$ of all tumours discovered in the gland represented metastatic malignant neoplasms. The majority of this series was squamous cell carcinomas. In 1990, Batsakis and Bautina (7) reported a series of 225 supraclavicular primary tumours that metastasized to parotid glands and parotid lymph nodes. Fifty-seven of these lesions (25\%) involved melanomas, the majority of which were of cutaneous origin. In our case, the patient had a history of excision of melanoma from the forehead six months previously.

Theoretically, melanomas can be seen in the parotid gland. Takeda (8) presented that melanocytes can exist in the intralobar duct of the parotid gland in an autopsy case. These melanocytes could potentially serve as cells of origin for primary melanoma of the gland. Cases of primary melanomas arising in the parotid gland have been reported in the literature; in a portion of these patients it is still controversial whether or not the tumours were metastatic. Greene and Bernier (9) also noted that primary parotid melanomas were not located in lymph nodes. The tumours were invasive and poorly demarcated. Regression of a primary cutaneous melanoma is known to ocur $(2,4)$. Smith and Stehlin (10) reported spontaneous regression of primary melanoma with regional metastases; in eight of 456 cases of metastatic melanoma, $1.7 \%$ were with unknown primary cutaenous lesions.

Woodward and colleagues (11) proposed that four conditions should be met before rendering a diagnosis of primary parotid melanoma. These include the following criteria: i) the tumour epicenter is within the parotid: ii) -there is no identifiable lymph node tissue present in the mass: iii) -there is no evidence of melanoma elsewhere in the body and iv) -there is no evidence of previous excisions of melanoma or progression 
of a pigmented lesion. In our case, the tumour had infiltrated the parotid lymph nodes and the parotid glands on both sides.

They typically manifest as slowly enlarging, solitary, fixed masses in the parotid region, but a few are multinodular and/ or fixed to skin or muscle. Tumours may be associated with facial nerve palsy $(2,12)$. Regional or distant metastasis can be observed. It was reported that the incidence of the regional lymph node involvement increases with the thickness of the tumour. Involvement of the regional lymph nodes is extremely rare in melanomas with a thickness of $<0.76 \mathrm{~mm}$ (3).

Metastatic melanoma with its variable morphological features is a great histopathological dilemma and it may be confused with tumours of nearly all lineages. Immunohistochemichemistry can be helpful in delineating the lineage of the tumour. Immunohistochemically S-100 and HMB-45 is positive in melanoma in the majority of cases. In a study published in 2004 assessing the sensitivity of routine immunohistochemical markers on metastatic deposits in lymph nodes, $98 \%$ of cases (123 of 126) stained positive for S100 protein, $82 \%$ (103 of 126) for MART-1 (melan-A), and 76\% (95 of 125) for HMB-45 (13).

In our case, S100 stained positive and HMB-45 had focal positive, but was negative in the large areas. So we used MART-1 for differential diagnosis and it was assessed as positive.

Surgery is the first choice in the treatment of tumour tissue. Superficial parotidectomy with neck dissection is recommended. However, excision of the primary tumour, in addition to this process, should be performed $(2,3)$. Also, radiotherapy, chemotherapy and immunotherapy options, alone or in combination protocols, are proposed according to the pathological stage (12).

There is controversy about whether the prognosis for lesions with an unknown primary is better than the prognosis for tumours in which the primary is known. In general, most patients with parotid gland involvement by melanoma have a poor clinical prognosis. Santini and colleagues (14) showed that the survival rate for patients with unknown primary tumour sites was better than that for patients with known pri- mary tumour sites. Wang and colleagues (2) data also support this contention.

In conclusion, bilateral parotid metastases from a cutaneous melanoma are quite rare. According to our knowledge, our case is the first case in the English literature. Treatment and prognosis are different from the primary parotid gland tumours. It is important to keep in mind melanoma in the differantial diagnosis.

\section{REFERENCES}

1. American Cancer Society. Cancer Facts and Figures 2011; 2011: 1-60. Available from: http://www.cancer.org/Research/CancerFactsFigures/ CancerFactsFigures/cancer-facts-figures-2011. Accessed January $16,2012$.

2. Wang BY, Lawson W, Robinson RA, Perez-Ordonez B, Brandwein M. Malignant melanomas of the parotid: comparison of survival for patients with metastases from known vs unknown primary tumor sites. Arch Otolaryngol Head Neck Surg 1999; 125: 635-9.

3. Yörük Ö, Yaşar M, Aktan B, Üçüncü H, Kılıç K. Parotis bezini malign melanom metastazı. Eurasian J Med Apr 2007; 39: 75-7.

4. Prayson RA, Sebek BA. Parotid gland malignant melanomas. Arch Pathol Lab Med 2000; 124: 1780-4.

5. Andreadis D, Poulopoulos A, Nomikos A, Epivatianos A, Barbatis C. Diagnosis of metastatic malignant melanoma in parotid gland. Oral Oncology Extra 2006; 42: 137-9.

6. Yarington, CT Jr. Metastatic malignant disease to the parotid gland. Laryngoscope 1981; 91: 517-19.

7. Batsakis JG, Bautina E. Metastases to major salivary glands. Ann Otol Rhinol Laryngol 1990; 99: 501-3.

8. Takeda Y. Melanocytes in the human parotid gland. Pathol Int 1997; 47: 581-3.

9. Greene GW Jr, Bernier JL. Primary malignant melanomas of the parotid gland. Oral Surg 1961; 14: 108-16.

10. Smith JL Jr, Stehlin JS Jr. Spontaneous regression of primary malignant melanomas with regional metastases. Cancer 1965; 18: 1399-1415.

11. Woodward RT, Shepard NA, Hensher SR. Malignant melanoma of the parotid gland: a case report and literature review. Br J Oral Maxillofac Surg1993:76plokijuhygtfrdswq=-098UYTREWQRQWSAZAZxcvgbhnjk,./1: 313-5.

12. Bahar M, Anavi Y, Abraham A, Ben-Bassat M. Primary malignant melanoma in the parotid gland. Oral Surg Oral Med Oral Pathol 1990; 70: $627-30$.

13. Ord RA. Metastatic melanoma of the parotid lymph nodes. Int J Oral Maxillofac Surg 1989; 18: 165-7.

14. Santini H, Byers RM, Wolf PF. Melanoma metastatic to cervical and parotidnodes from an unknown primary site. Am J Surg 1985; 150: 510-2. 